\title{
Penerapan Pendekatan Saintifik dengan Media Muatan dalam Peningkatan Pembelajaran Matematika Tentang Bilangan Bulat pada Siswa Kelas IV SDN 2 Kebumen Tahun Ajaran 2017/2018
}

\author{
Rizki Amalia ${ }^{1}$, Wahyudi², M. Chamdani ${ }^{3}$ \\ 1,2,3 Universitas Sebelas Maret \\ ramalia879@gmail.com
}

\section{Article History}

accepted 01/02/2019

published 01/04/2019

\begin{abstract}
The objective of this research is to improve Mathematics learning about integers through the implementation of scientific approach using load media. This research is a collaborative Classroom Action Research (CAR) conducted within three cycles. Subjects of the research were 22 students of the fourth-grade of SDN 2 Kebumen. Validity of data in this research was analyzed using triangulation of technique and triangulation of sources. The results showed that the application of scientific approach using load media can improve Mathematics learning about integers for the fourth-grade students of SDN 2 Kebumen in the academic year of 2017/2018. It was proven by the increase of learning process percentage of Mathematics in the first cycle $85.66 \%$, in the second cycle $87.88 \%$, and in the third cycle $91.52 \%$. In addition, the increase of learning outcomes percentage of Mathematics in the first cycle $88.41 \%$, in the second cycle $90.47 \%$, and in the third cycle $93.18 \%$. The conclusion of this research is the application of scientific approach using load media can improve the Mathematics learning about integers for the fourth-grade students of SDN 2 Kebumen in the academic year of 2017/2018.
\end{abstract}

Keywords: scientific approach, load media, integers

\begin{abstract}
Abstrak
Tujuan penelitian ini yaitu untuk meningkatkan pembelajaran matematika tentang bilangan bulat pada siswa kelas IV SDN 2 Kebumen tahun ajaran 2017/2018. Penelitian ini merupakan penelitian tindakan kelas tipe kolaboratif melalui tiga siklus yang terdiri dari tahap perencanaan, pelaksanaan, pengamatan, dan refleksi. Teknik pengumpulan data berupa observasi, wawancara, dan tes. Validitas data pada penelitian ini menggunakan triangulasi sumber dan triangulasi teknik. Hasil penelitian ini menunjukkan bahwa penerapan pendekatan saintifik dengan media muatan dapat meningkatkan pembelajaran matematika tentang bilangan bulat pada siswa kelas IV SDN 2 Kebumen tahun ajaran 2017/2018. Hal ini dibuktikan dengan persentase ketuntasan proses belajar matematika pada siklus I $=85,66 \%$, siklus $I I=87,78 \%$, siklus III = 91,52\%. Lalu, ketuntasan hasil belajar matematika pada siklus I $=88,41 \%$, siklus II = $90,47 \%$, siklus III $=93,18 \%$. Simpulan dalam penelitian ini adalah penerapan pendekatan saintifik dengan media muatan dapat meningkatkan pembelajaran matematika tentang bilangan bulat pada siswa kelas IV SDN 2 Kebumen tahun ajaran 2017/2018.
\end{abstract}

Kata Kunci: pendekatan saintifik, media muatan, bilangan bulat 


\section{PENDAHULUAN}

Pendidikan mempunyai andil yang sangat besar pada kualitas yang dimiliki oleh seseorang. Hal ini dikarenakan pendidikan dapat membantu manusia untuk menjadi insan yang takwa terhadap Tuhan yang Maha Esa, bertanggung jawab, cerdas, dan mampu mencapai tujuannya. Undang-Undang Republik Indonesia Nomor 20 Tahun 2003 tentang Sistem Pendidikan Nasional Pasal 1 ayat 1, menjelaskan bahwa pendidikan merupakan suatu usaha yang terencana untuk menciptakan suasana belajar dan proses pembelajaran supaya peserta didik dapat dengan aktif menumbuhkan potensi agar mempunyai kekuatan spiritual, keagamaan, pengendalian diri, kepribadian, kecerdasan, akhlak mulia, serta keterampilan yang dibutuhkan dirinya, masyarakat, bangsa, dan negara.

Matematika merupakan ilmu yang dapat menambah kemampuan berargumentasi seseorang serta dapat membantu menyelesaikan masalah kehidupan sehari-hari, menunjang perkembangan ilmu pengetahuan dan teknologi (Susanto, 2016: 185). Wahyudi (2015: 68) menyatakan bahwa matematika adalah kajian ilmu yang mempunyai objek abstrak serta dirancang dengan proses penalaran deduktif. Untuk memudahkan peserta didik dalam mempelajari matematika tentang bilangan bulat, ketika proses pembelajaran perlu menerapkan pendekatan yang sesuai.

Berdasarkan pengamatan awal proses pembelajaran di kelas IV SDN 2 Kebumen, pembelajaran yang dilaksanakan sudah baik hanya saja masih berpusat pada guru dan guru belum menggunakan pendekatan pembelajaran yang tepat serta hanya menerapkan metode ceramah dan menerapkan metode drill (mengerjakan latihan) saat menyampaikan materi pelajaran. Hasil belajar siswa masih tergolong belum maksimal, dengan nilai KKM yang tergolong rendah namun masih banyak siswa nilainya masih dibawah KKM. Hal ini ditunjukkan dengan hasil ulangan harian matematika tentang bilangan dari 21 siswa, hanya 14 siswa yang telah mencapai Kriteria Ketuntasan Minimal (KKM), sedangkan 7 siswa lainnya belum mencapai Kriteria Ketuntasan Minimal (KKM) yang telah ditentukan yaitu 64. Selain itu, ulangan harian matematika memiliki nilai rata-rata terendah dibandingkan dengan nilai rata-rata mata pelajaran yang lain.

Inovasi pembelajaran dibutuhkan untuk mengatasi permasalahan tersebut. Salah satu inovasi yang dapat dilaksanakan yaitu dengan memadukan pendekatan dengan media yang tepat. Solusi yang dianggap tepat yaitu dengan menerapkan pendekatan saintifik dengan media muatan.

Pendekatan saintifik merupakan suatu pendekatan pembelajaran yang diharapkan dapat membuat peserta didik aktif dalam menemukan suatu pengetahuan baru, sehingga pengetahuan yang didapat tidak hanya berasal dari guru (Hosnan, 2014: 34). Langkah-langkah pendekatan saintifik menurut Dyer (Sani, 2014: 53) yaitu: (a) mengamati, (b) menanya, (c) mencoba/mengumpulkan informasi; (d) menalar, (e) melakukan komunikasi.

Media muatan yaitu media yang dipergunakan untuk memudahkan siswa dalam mempelajari matematika mengenai bilangan bulat (Wahyudi, 2015: 144). Menurut Muhsetyo, G, dkk (2008: 3.11) yang dimaksud dengan alat peraga manik-manik dalam menghitung operasi bilangan bulat adalah media muatan, hanya pada namanya yang berbeda.

Berdasarkan uraian di atas, dapat disimpulkan bahwa pendekatan saintifik dengan media muatan pada pembelajaran matematika tentang bilangan bulat yaitu suatu pendekatan ilmiah yang dirancang untuk memberikan materi pembelajaran dengan melibatkan siswa, agar siswa aktif ketika mengikuti proses pembelajaran dengan beberapa langkah yang terdiri dari: (1) mengamati dengan media muatan, (2) menanya dengan media muatan, (3) menalar dengan media muatan, (4) mencoba dengan media muatan, (5) mengomunikasikan hasil dengan media muatan. 
Rumusan masalah pada penelitian ini yaitu apakah penerapan pendekatan saintifik dengan media muatan dapat meningkatkan pembelajaran matematika tentang bilangan bulat pada siswa kelas IV SDN 2 Kebumen tahun ajaran 2017/2018?

Tujuan penelitian ini yaitu untuk meningkatkan pembelajaran matematika tentang bilangan bulat melalui penerapan pendekatan saintifik dengan media muatan pada siswa kelas IV SDN 2 Kebumen tahun ajaran 2017/2018.

\section{METODE}

Penelitian ini dilaksanakan di kelas IV SDN 2 Kebumen, Kecamatan Kebumen, Kabupaten Kebumen. Subjek pada penelitian tindakan kelas ini yaitu 22 siswa yang terdiri dari 13 siswa laki-laki dan 9 siswa perempuan. Penelitian ini dilaksanakan mulai bulan Oktober 2017 sampai dengan bulan April 2018.

Teknik pengumpulan data dalam penelitian ini menggunakan instrument berupa lembar observasi terhadap guru dan siswa, pedoman wawancara, dan lembar tes. Proses analisis data dalam penelitian ini mengacu pendapat Miles dan Huberman (Sugiyono, 2012: 337) yang meliputi reduksi data, penyajian data, dan penarikan kesimpulan. Teknik uji validitas data penelitian ini menggunakan teknik triangulasi yaitu triangulasi sumber dan triangulasi teknik. Indikator kinerja dalam penelitian ini yaitu mencapai $85 \%$.

Penelitian tindakan kelas ini dilaksanakaan dalam tiga siklus. Prosedur penelitian yang digunakan yaitu perencanaan, pelaksanaan, pengamatan, refleksi (Arikunto, 2013: 138).

\section{HASIL DAN PEMBAHASAN}

Penerapan pendekatan saintifik dengan media muatan dalam peningkatan pembelajaran matematika meliputi dua aspek yaitu proses dan hasil belajar siswa yang dilaksanakan selama tiga siklus. Data hasil pengamatan dari 3 observer terkait penerapan pendekatan saintifik dengan media muatan sebagai berikut.

Tabel 1. Hasil Observasi terhadap Guru dan Siswa

\begin{tabular}{ccc}
\hline Siklus & $\begin{array}{c}\text { Guru } \\
(\%)\end{array}$ & $\begin{array}{c}\text { Siswa } \\
(\%)\end{array}$ \\
\hline I & $85,66 \%$ & $85,73 \%$ \\
\hline II & $87,78 \%$ & $86,99 \%$ \\
\hline III & $91,52 \%$ & $90,67 \%$ \\
\hline
\end{tabular}

Berdasarkan tabel 1, dapat diketahui bahwa penerapan pendekatan saintifik dengan media muatan oleh guru mengalami peningkatan dari siklus I yaitu $85,66 \%$, siklus II yaitu $87,78 \%$, siklus III yaitu $91,52 \%$. Data tersebut menunjukkan bahwa guru dalam melaksanankan pembelajaran dengan menerapkan pendekatan saintifik dengan media muatan telah berhasil.

Hasil observasi terhadap respon siswa pada siklus I yaitu $85,73 \%$, siklus II yaitu $86,99 \%$, dan siklus III yaitu $90,67 \%$. Hal tersebut menunjukkan bahwa pelaksanaan pembelajaran dengan menerapkan pendekatan saintifik dengan media muatan direspon baik oleh siswa.

Selain hasil observasi terhadap guru dan siswa, berikut ini peningkatan persentase ketuntasan hasil belajar siswa antarsiklus:

Tabel 2 Perbandingan Ketuntasan Hasil Belajar Siswa 
Volume 7 Nomor 1 Tahun 2019

\begin{tabular}{lcc}
\hline \multirow{2}{*}{ Tindakan } & \multicolumn{2}{c}{$\begin{array}{c}\text { Perolehan Hasil } \\
\text { Belajar Siswa }\end{array}$} \\
\cline { 2 - 3 } & $\begin{array}{c}\text { Belum } \\
\text { Tuntas } \\
(\%)\end{array}$ & $\begin{array}{c}\text { Tuntas } \\
(\%)\end{array}$ \\
\hline Siklus I & 11,59 & 88,41 \\
Siklus II & 9,53 & 90,47 \\
Siklus III & 6,82 & 93,18 \\
\hline
\end{tabular}

Berdasarkan tabel 2, persentase ketuntasan hasil belajar siswa mengalami peningkatan. Pada siklus I persentase ketuntasan siswa $88,41 \%$. Pada siklus II $90,47 \%$, dan pada siklus III meningkat menjadi 93,18\%. Data tersebut menunjukkan bahwa persentase ketuntasan hasil belajar siswa telah mencapai indikator kinerja penelitian sebesar $85 \%$. Hal tersebut relevan dengan hasil penelitian yang dilakukan oleh Urohmah, Wahyudi, dan Budi (2015: 228) yang menunjukkan bahwa penerapan pendekatan saintifik dapat meningkatkan pembelajaran matematika.

\section{SIMPULAN}

Berdasarkan analisis pelaksanaan penelitian dan pembahasan, dapat disimpulkan bahwa penerapan pendekatan saintifik dengan media muatan dapat meningkatkan pembelajaran matematika tentang bilangan bulat pada siswa kelas IV SDN 2 Kebumen tahun ajaran 2017/2018.

Berdasarkan hasil penelitian dan pembahasan, peneliti memberi saran sebagai berikut: (1) bagi siswa, sebaiknya lebih aktif dalam mengikuti pembelajaran, (2) guru dapat menjadikan pendekatan saintifik dengan media muatan sebagai salah satu alternatif untuk meningkatkan pembelajaran matematika tentang bilangan bulat pada siswa kelas IV SD, (3) bagi sekolah, sebaiknya memberi fasilitas pada guru agar dapat meningkatkan pembelajaran, (4) bagi peneliti hendaknya lebih memahami tentang pendekatan saintifik, media muatan, dan hal lain yang berkaitan dengan penelitian ini.

DAFTAR PUSTAKA

Arikunto, S. (2013). Prosedur Penelitian, Suatu Pendekatan Praktik. Jakarta: Asdi Mahasatya.

Hosnan. (2014). Pendekatan Saintifik dan Kontekstual dalam Pembelajaran Abad 21. Bogor: Ghalia Indonesia.

Muhsetyo, G, dkk. (2008). Pembelajaran Matematika SD. Jakata: Universitas Terbuka.

Sani, R. A. (2014). Pembelajaran Saintifik untuk Implementasi Kurikulum 2013. Jakarta: PT Bumi Aksara.

Sugiyono. (2012). Metode Penelitian Pendidikan: Pendekatan Kuantitatif, Kualitatif, dan $R \& D$. Bandung: Penerbit Alfabeta.

Susanto, A. (2016). Teori Belajar Pembelajaran. Jakarta: Kencana.

Undang-Undang Nomor 20 Tahun 2003 tentang Sistem Pendidikan Nasional 